\title{
An Update on Nearshore Berms in the Corps of Engineers: Recent Projects and Future Needs
}

\author{
by Tanya M. Beck, Julie D. Rosati, and James Rosati
}

PURPOSE. This Coastal and Hydraulics Engineering Technical Note (CHETN) documents a recently completed nearshore berm placement study, and summarizes knowledge to date for placement of dredged sediment as nearshore berms.

INTRODUCTION. Dredging of Corps navigation projects results in millions of cubic yards of sediment displaced each year. Many options for placement of the material exist, including Beneficial Use through creation of islands or wetlands, upland and offshore placement, direct beach placement, and nearshore placement. In recent years, the Corps' project-centric focus has changed toward a more systematic approach that considers the sediment to be a valuable resource as part of the regional littoral system. The Corps' Regional Sediment Management (RSM) Program supports active research on, and support for, modifying outdated project guidelines with new systematic approaches toward managing sediment as a resource.

Nearshore berm placement is one RSM approach presently used by US Army Corps of Engineers (USACE) Districts that has the potential to provide an immediate benefit to beaches. As sediment is removed out of a littoral system through dredging, placement in the nearshore reintroduces the sediments to an adjacent littoral region that preserves valuable sediment resources that would have been lost otherwise to the nearshore system. The physical benefits of this practice to the adjacent beaches include wave attenuation and adding material to the nearshore beach profile that may be reworked by processes and migrate onshore. When in place, berms pose minimal impact to the environment if placed in what is typically an active littoral zone. Questions as to whether fines migrate onshore or disturb subaqueous habitat during the placement process and degrade water quality through suspension for some time following the placement must be addressed on a site specific basis.

Here, we define the nearshore berm as dredged sediment that can be placed in deeper water as a mound to be stationary while attenuating waves as a "stable berm," or can be placed in a shoreparallel form in shallower water as an active "feeder berm" (McLellan and Kraus 1991). To keep construction costs low and facilitate direct placement from dredges, berm placement has been limited generally to deeper water depths and the shortest travel distance to the placement location. Monitoring of shallower feeder berms has been limited. Many long-standing disposal sites such as Mobile Bay's Stable Berm, AL, and the disposal site at Morehead City, NC, have been monitored and only recently have been categorized as "stable" placement sites. These monitoring data on stable placement sites provide insight on the behavior of stationary nearshore placements, but data for migrating nearshore berms in similar detail and quantity is limited.

PRIOR STUDIES ON BERMS. Extensive studies on design considerations for nearshore berm placements were conducted in the late 1980s to mid-1990s, with several papers funded by 
the Dredging Research Program (DRP) (Allison and Pollock 1993, McLellan and Kraus 1991, McLellan 1990). Several of these studies cite the Hallermeier index (Hallermeier 1978, 1981a, 1981b, 1983), which defines the active littoral zone where significant net transport occurs, referred to as the seaward limit of intense to intermediate bed activity. Sediment placed deeper than this seaward limit will not affect wave energy significantly or evolve with time. Sediment placed shallower than Hallermeier's outer seaward limit would be more mobile, and can be subdivided into two types, a feeder berm and a stable berm (McLellan and Kraus 1991). Feeder berms are high-relief, linear, and shore-parallel berms that both reduce wave energy and transport material shoreward under accretionary conditions. A stable berm may be high- or low(thin layer disposal) relief and can also attenuate high wave energy under some conditions, but is not intended to migrate.

McLellan and Kraus (1991) defined steps for determining the potential success of a nearshore dredged placement in the form of a berm that consisted of sediment dredged from an adjacent navigation channel and was placed in the nearshore downdrift of the channel. These steps included assessing the quantity and quality of material, availability of equipment, local (wave) conditions, and economics of berm construction and alternatives. The actual design of the berm would then be evaluated for these following factors:

- location of placement proximal to navigation channel influence,

- timing of placement, which could be seasonally dependent,

- depth of berm in an active location, and

- the overall dimensions of the constructed berm to reduce wave focusing.

The placement location of a feeder berm, different from a stable berm placed farther offshore, would need to consider sites with minimal inlet-related tidal currents that would be modified primarily under wave forcing over a nonuniform bathymetry. Seasonal timing of placement in the northern hemisphere is typically best at the beginning of summer when there are more accretional-type wave conditions. Finally, the dimensions and depth of placement should be considered to optimize onshore migration of sand to the beach.

Early conceptual numerical modeling of the design dimensions including height, width, length, and end slopes were evaluated by McLellan and Kraus (1991) and Allison and Pollock (1993). These studies conducted by the DRP culminated in a stability graph developed by Hands and Allison (1991) (Figure 1). This graph illustrates the stability of berm projects based on their depth and whether this depth is shallower or deeper as compared to the Inner and Outer Depth Of Closure (DOC as defined by Hands and Allison 1991) limits (defined in Hallermeier 1981a, 1981b) as a direct relation to significant wave height and wave steepness. The inner and outer limits of the DOC are calculated using local sand characteristics and summary statistics of annual wave climate. The outer limit is defined by extreme yearly waves, and the inner limit is defined by the yearly median wave conditions. 


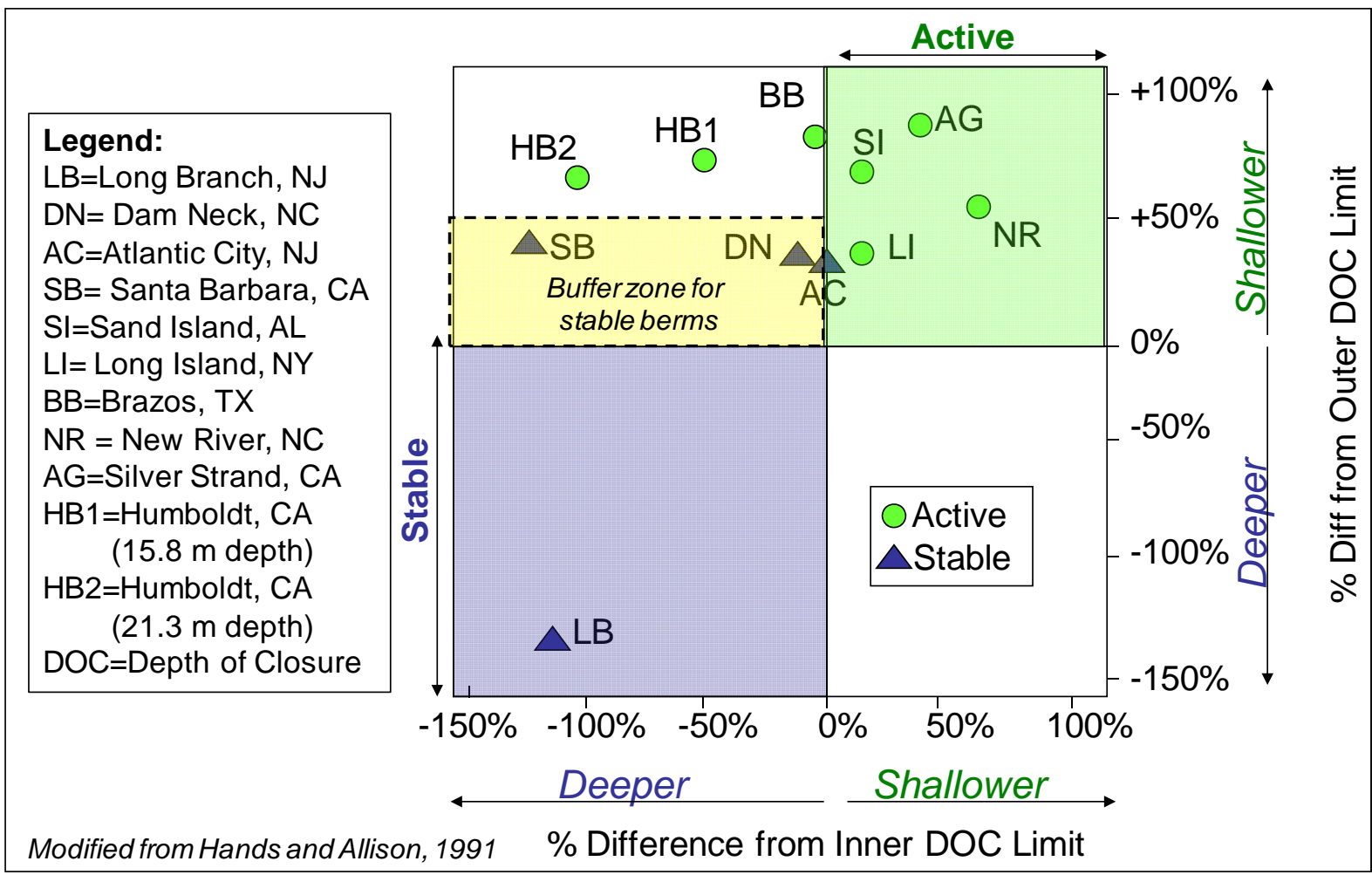

Figure 1. Hands and Allison (1991) nearshore berm stability graph illustrating the difference between active and stable berms in deep or shallow water.

Hallermeier (1981b) related the mean annual significant wave height, $H_{s}$, the associated standard deviation, $\sigma_{H s}$, mean significant wave period, $T_{s}$, and typical median sand diameter near the project site, $D$, as follows:

$$
\begin{aligned}
& D O C_{\text {outer }}=2 H_{s}+11 \sigma_{H_{s}} \\
& D O C_{\text {inner }}=\left(H_{s}-0.3 \sigma_{H_{s}}\right) T_{s} \sqrt{\frac{g}{5000 D}}
\end{aligned}
$$

The stability graph is intended to provide information as to whether a berm will be stable or migratory (active) based on the wave data available at the time of the Hands and Allison (1991) study. The buffer zone defined by Hands and Allison (1991) (upper left quadrant of Figure 1) contained stable berms that were placed between 0 and 50\% shallower than the Outer DOC Limit, but still were deeper than the Inner DOC Limit. Berms placed in locations with less than half the water depth of the Outer DOC tended to be active, indicating a potential cutoff point for active feeder berms.

\section{RECENT EXAMPLES OF BERM PROJ ECTS.}

Stable Berms. The variety of past nearshore berms and their associated objectives has produced different results and perspectives of what constitutes a nearshore berm. Some of the older nearshore placements resulted from a need to dispose of dredged sediments efficiently, without concern of re-entry into the navigation channel, resulting in a stable offshore berm. Two exemplary projects are the Mobile Stable Berm and the Galveston Beneficial Berm. Both were 
designed to be stable, long-term placement sites that also performed beneficially as fishery habitat. The Galveston Beneficial Berm was placed far from the navigation channel to prevent re-entry of sediment into the navigation channel. Dredged sediment from the Mobile navigation channel was placed in three different nearshore berms, of which the stable berm fulfilled its purpose of a stable, shortest-distance placement site.

Feeder or Active Berms. Feeder berm projects can be found along the entire American coastline, and can range significantly in size and periodicity. Smaller frequent projects that coincide with regular channel dredging (between 1-10 years) can be found next to small- to moderately-shoaling inlets such as Jones Inlet and Fire Island Inlet, NY, Perdido Pass and East Pass, FL, Manasquan Inlet and Shark River Inlet, NJ, and San Diego Harbor Entrance Channel, CA. The quantity of sand can vary from 10,000 cu yd (e.g., Shark River Inlet) to 300,000 cu yd (e.g., Jones Inlet), but the ultimate result of the design is rapid dispersion and migration of the sediments onshore. Some short-term monitoring studies focused on improved placement have examined sediment plume dispersal and the extent of transport of suspended sediments under tidal current influence, through sediment tracer studies. A recent example was a study conducted at the Brunswick Federal Entrance Channel (Smith et al. 2007, Gailani et al. 2007) to determine the winnowing effects on fine-grained sediment and the transport potential and direction of sands and fine-grained material. However, very few of these studies have documented evolution in morphology and sedimentologic stratigraphy of the placement.

Figure 2 shows a recent example of a substantially large, active berm. Sediment dredged from the San Francisco navigation channel extending through the outer bar has been placed three times, totaling 900,000 cu yd (Barnard et al. 2009). The material was placed offshore of a local erosional hot spot in the vicinity of Ocean Beach, CA. Sediments were placed in the nearshore to mitigate the intensive erosion along this beach through both wave attenuation and sediment supply. Findings from the Barnard et al. study indicated that approximately half of the sediment that has been placed in the nearshore dredge-disposal site during the 2.5 years of this study remained within the placement area. During the winter of 2006-2007, large waves transported this sediment onshore. Although some accretion has been recorded adjacent to the placement site, it is unclear whether this is related to the berm (Barnard et al. 2009).

The Fort Myers Berm in southwestern Florida (Figures 3 and 4) was constructed because of a need to nourish Fort Myers Beach. However, the dredged sediment from nearby Matanzas Pass had $>10 \%$ fines (silt and mud) and was not acceptable for subaerial placement, according to Florida State law. The linear berm indicated in Figure 4 was pumped into place $600 \mathrm{ft}$ offshore of the shoreline in less than $6 \mathrm{ft}$ of water depth. Depressional gaps in the linear feature were created during the placement process. These gaps allow return flow of onshore directed water and have been relatively stable in the 1.5 years since construction. The stability of the gaps may be related to rip current activity. Anecdotal evidence has indicated that these gaps are also beneficial for recreational entry/access to the beach (Brutsche and Wang 2011, Brutsche 2011).

PRESENT GUIDELINES FOR DESIGN AND MONITORING. Guidance required for nearshore berms can be separated into information pertinent to: the dredging and placement of berms; cross-shore and alongshore design as a function of sediment size and distribution, conditions at the placement site, and forcing processes; and post-placement monitoring. 


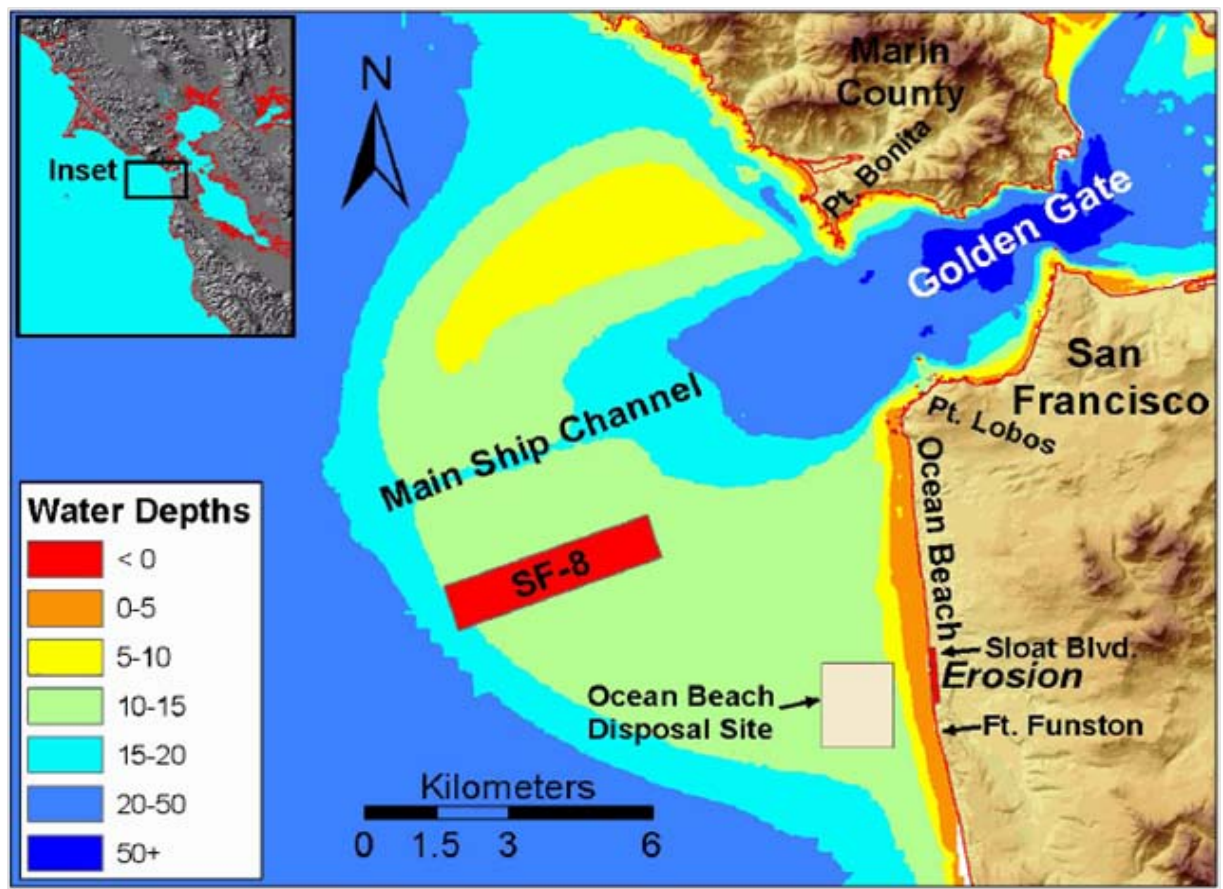

Figure 2. Nearshore berm placement adjacent to Ocean Beach in San Francisco, CA.

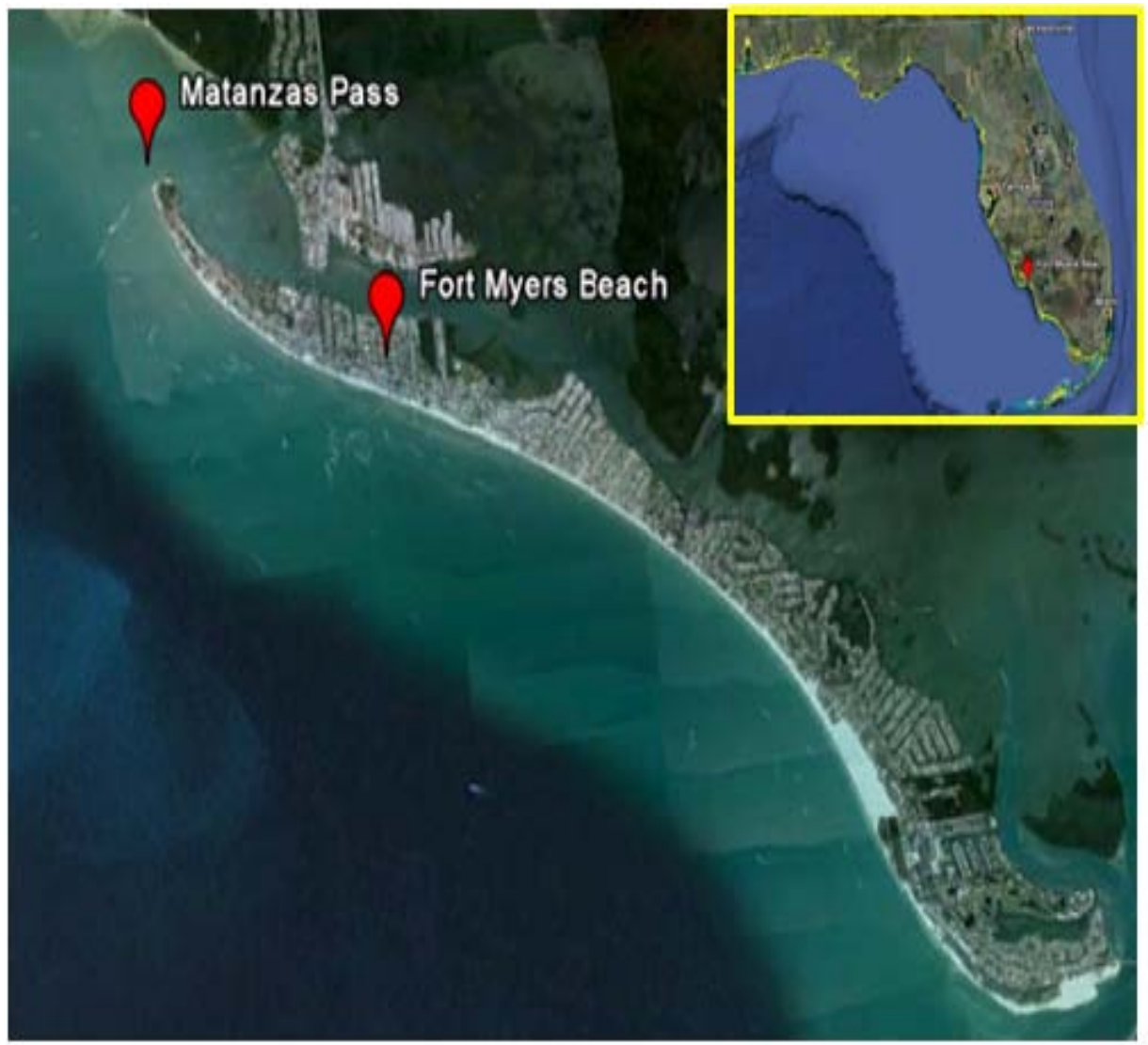

Figure 3. Fort Myers Beach and Matanzas Pass at the north end of Estero Island, FL. 


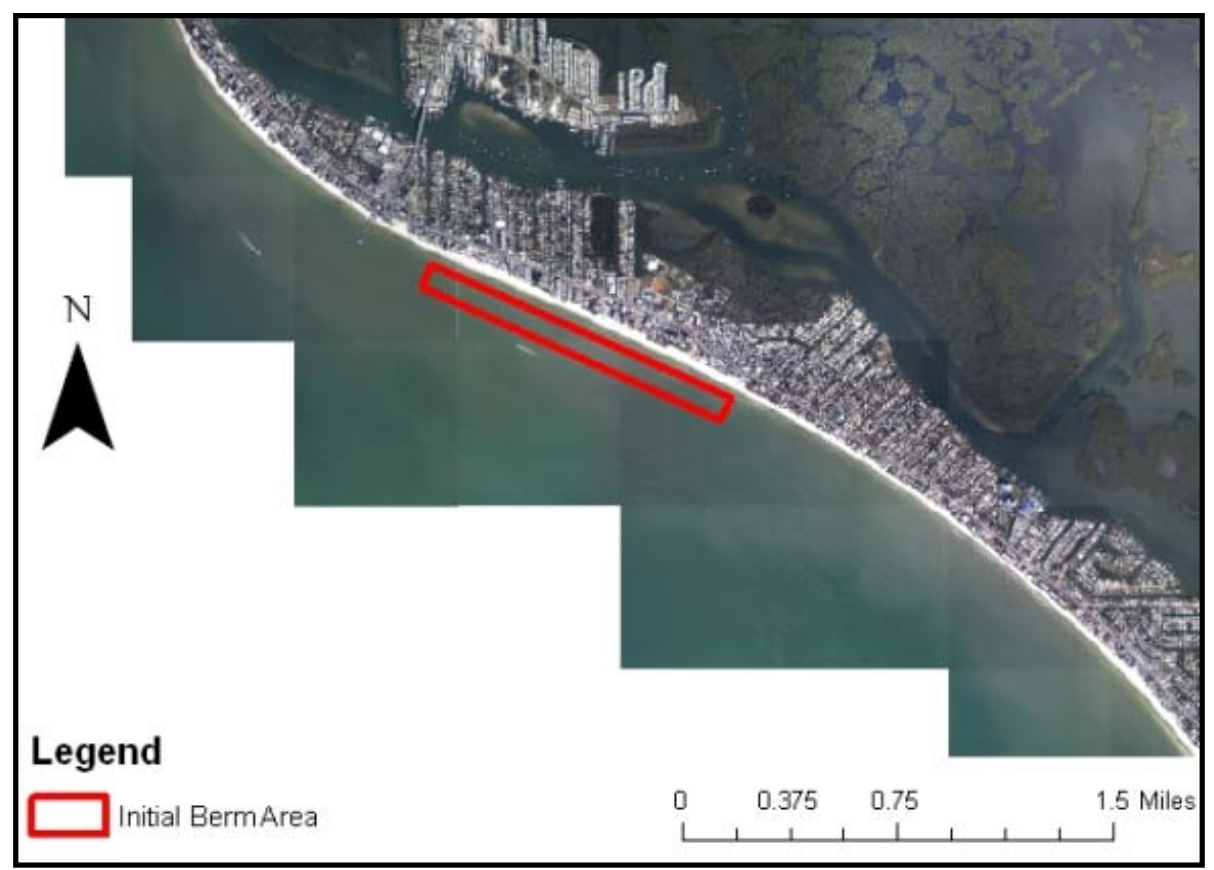

Figure 4. Designed berm placement location in shallow water (<6 ft), Fort Myers Beach, FL.

Dredging of Navigation Channels and Placement of Berms. Logistics of dredging and placement are subject to many interdependent requirements, such as the availability of dredges; the required depth of placement and capability of the dredge to place in those depths; distance traveled to the site; and attendant environmental requirements (e.g., turbidity limitations) at the site. All of these factors vary in importance from project to project. A single methodology for preparing operations for nearshore berm design is not a practical approach for all locations; however, those listed here are standard and necessary for most applications. Though some nearshore berm sediments may be from an offshore site, most contemporary nearshore placements are the result of planned dredging to maintain navigation channels. Dredging a specific channel or shoal is the priority of Operations and Maintenance (O\&M) and, therefore, specifics to that location such as quantity, quality of material, and location and depth of dredging are generally predetermined (McLellan and Kraus 1991).

Based on this information, an available dredge must be selected. This is often dependent on what type of dredge is available, if the dredge can operate within both the dredging and placement depths, and if it can operate in the appropriate environmental windows (times when dredging and placement activities may be conducted because regulators have determined that adverse impacts associated with these activities would not exceed known or perceived thresholds). There are three primary dredging operations that result in containment of the material so that it may be transported: (1) bucket or cutterhead pipeline dredges with scow transport, (2) cutterhead pipeline dredges, and (3) hopper dredges. The pipeline dredge pumps sediment in the form of a slurry (sediment and water mixture) from the dredged location to the placement site, whereas the hopper and bucket dredges are limited to certain operational depths. McLellan (1990) described the available dredges and their capacity to dredge and place sediment for a range of sites. The Cost Engineering Dredge Estimating Program (CEDEP) is a decision-support and cost-estimate tool that provides the availability and suitability of a particular dredge for a site-specific berm 
placement as a function of cost; however, there is little guidance for projects that have flexibility in determining the most beneficial placement sites with respect to the physical setting of the nearshore berm.

Cross-shore and Alongshore Design Guidance. Cross-shore design guidance for berms is limited to the depth of placement for stability versus active berms, as shown in the Hands and Allison (1991) stability chart (Figure 1). Limited guidance is available for: (1) how berms should be designed in cross-section (Allison and Pollock 1993), (2) the best placement location relative to the dredged channel as a function of prevailing processes, (3) temporal and spatial scales of migration, (4) the proper alongshore extent of the berm, and (5) whether gaps should be included as part of the design.

Monitoring Guidance. Presently, the Corps of Engineers does not require monitoring of a completed nearshore berm placement; however, individual states or local sponsors may require monitoring. From a national perspective, more monitoring is required to understand the benefits of the berm and the resulting temporal and spatial scales of evolution. Basic guidance for monitoring to understand berm performance can be gleaned from the Fort Myers, FL, project. Profile survey lines should be taken from the crest of the subaerial beach (berm crest) to the depth of closure, spaced 100 to $500 \mathrm{ft}$ apart to capture a minimum of 10 to 20 profiles over a morphologic end unit (or total length of placement). For mixed-sediment placement, sediment samples should be taken in the cross-shore every 10 to $100 \mathrm{ft}$ to account for the cross-shore distribution of sediments from the beach berm, swash zone, nearshore trough, leeward slope of berm, crest of berm, stoss slope of berm, and offshore. These samples should be analyzed for mean grain size. Where locations are suitable for airborne LIDAR topographic and bathymetric data collection, this method can provide high resolution, three-dimensional surface comparisons of nearshore morphology change. In addition to placement monitoring, adjacent "control” beach profiles should be measured with similar sediment sampling. All data should be measured at least annually (same time of the year), or better, semi-annually (post-winter and post-summer). Table 1 summarizes the optimal monitoring program for nearshore berms over a 1- to 3-year period. Monitoring is encouraged over the duration that the feature is measurable.

RSM, DOER, AND CIRP NEARSHORE BERM RESEARCH. The USACE Regional Sediment Management (RSM) Program, the Dredging Operations and Environmental Research (DOER) Program, and the Coastal Inlets Research Program (CIRP) have joined efforts in collaboration with the Jacksonville District (SAJ) and the University of South Florida (USF) to monitor and study two nearshore berm placement sites (Fort Myers and Egmont Key) located in Florida. The objectives of these studies are to conduct detailed monitoring and analysis of each nearshore berm placement, including: (1) sediment dispersion during the placement process (Egmont Key), (2) dense survey coverage of the beach and nearshore morphology change, (3) sedimentologic characteristics of the surface and subsurface, (4) long-term measurements of the nearshore wave climate, (5) numerical modeling, and (6) a short-term hydrodynamic study. These investigations will provide the essential background for guidance on design and monitoring of nearshore berms to determine project performance, can be used by the District doing work in the region of study, and will provide the background for general guidance and a template for design. 
ERDC/CHL CHETN-XIV-19

J anuary 2012

Table 1. Optimal monitoring program for a nearshore berm placement project spanning 1 to 3 years*

\begin{tabular}{|c|c|c|c|c|c|c|c|c|c|}
\hline \multirow[b]{2}{*}{$\begin{array}{l}\text { Monitoring } \\
\text { Component }\end{array}$} & \multicolumn{2}{|c|}{$\begin{array}{c}\text { Initial } \\
\text { Placement }\end{array}$} & \multicolumn{4}{|c|}{ Year 1 Following Initial Placement } & \multicolumn{2}{|c|}{ Years 2 to 3} & \multirow{2}{*}{$\begin{array}{l}\text { Years } 1 \text { to } 3 \\
\text { Post-s torm } \\
\text { Contingency }\end{array}$} \\
\hline & $\begin{array}{l}\text { Pre- } \\
\text { berm }\end{array}$ & $\begin{array}{l}\text { Post- } \\
\text { berm }\end{array}$ & Mar & Jun & Sep & Dec & Mar & Sep & \\
\hline $\begin{array}{l}\text { Beach profile } \\
\text { surveys }\end{array}$ & $x$ & $x$ & $x$ & $X^{* \star}$ & $x$ & $X^{\star \star}$ & $x$ & $x$ & $x$ \\
\hline $\begin{array}{l}\text { Sediment } \\
\text { sampling }\end{array}$ & $x$ & $x$ & & & $x$ & & & $x$ & \\
\hline Sediment Cores & & $x$ & & & & & & $x$ & \\
\hline $\begin{array}{l}\text { Waves and water } \\
\text { levels }\end{array}$ & \multicolumn{6}{|c|}{$\leftarrow-------C o n t i n u o u s$ Measurements-------( } & & & \\
\hline \begin{tabular}{|l} 
Aerial \\
photography
\end{tabular} & $x$ & & & & $x$ & & & $x$ & \\
\hline
\end{tabular}

Fort Myers Berm. In October 2010, SAJ dredged Matanzas Pass (southwest coast of Florida) and placed the dredged material in a nearshore berm at Fort Myers Beach, FL. Semiannual surveys have been conducted by SAJ since that time. The USF has been monitoring profile change during this period within the placement area and adjacent beaches, as well as the sedimentological evolution of the berm. The USF has completed two full surveys and extensive surface sedimentologic data collection and analysis. There is early indication of onshore berm migration and minimal shoreline change (Brutsche and Wang 2011). Over the first year of monitoring, sedimentologic results indicate dispersion of finer sediments downdrift and offshore of the natural bar over the control area. Results indicate that the project design was successful, as sand-sized sediments are migrating onshore and finer sediments are moving offshore. Gaps in the segmented berm have remained intact and have migrated alongshore from 150 to $300 \mathrm{ft}$.

Other Locations within the Gulf Intracoastal Waterway (GIWW). In the fall of 2011, SAJ plans to dredge Longboat Pass, FL, and four other locations within the GIWW, and will place the dredged material as a nearshore berm offshore of Egmont Key (Figure 5). These sediments will include more than $10 \%$ fines, which is the State of Florida's limit for onshore placement. SAJ's purpose for placing the material within a nearshore berm is to keep the sediments in the littoral system offshore of Egmont Key, which will use the dredged material beneficially to reduce shoreline erosion and improve environmental habitat. Egmont Key is a Florida State Park, and National Wildlife Refuge, and is located along a natural confluence of sediments at the main entrance to Tampa Bay. Over recent decades, significant erosion has occurred along the Gulf shoreface, reducing subaerial habitat and limiting the capacity of the park to operate as a wildlife refuge in a highly populated stretch of coastline. Design of the berm placement will depend on logistics as well as dredged sediment size. 


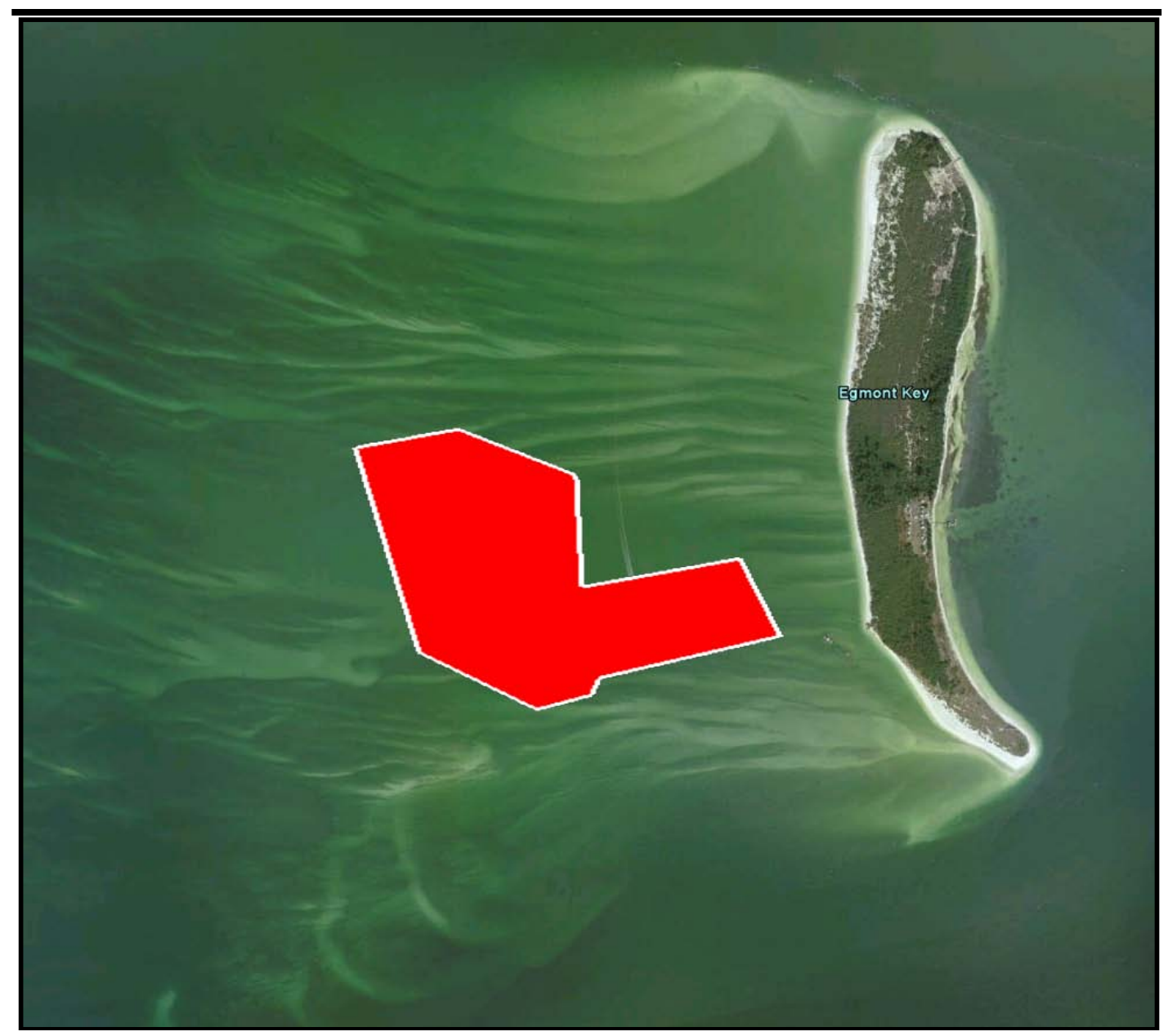

Figure 5. Nearshore berm placement planned for offshore of Egmont Key, FL. Note that the shape of the placement area reflects cultural resource zoning due to the presence of a $19^{\text {th }}$ century fort.

RESEARCH OBJ ECTIVES. Given our experience and understanding to date, objectives have been established for future berm research as follows:

- Develop guidance for logistics and operations pertaining to dredging for berm placement, including the types of dredges and relative costs associated with berm placement, the depth of placement corresponding to dredge type, and associated relative costs.

- Document experiences to date through an online portal that can be accessed by District offices.

- Develop decision-support information as to the availability and suitability of a particular dredge for a site-specific berm placement, as a function of cost.

- Develop a simple, fast calculator to estimate berm response as a function of the prevailing wave climate, sediment grain size and distribution, and initial conditions.

- Develop guidance for application of numerical models to design and calculate response of nearshore placement. Estimate the dispersal of fines, and whether these impact adjacent habitat. Calculate long-term migration of the berm, including selective transport of mixed sediment. 
SUMMARY. This Coastal and Hydraulics Engineering Technical Note (CHETN) has summarized the state-of-knowledge pertaining to nearshore placement of dredged sediment in the form of a morphologic feature called a nearshore berm. Information gleaned from the literature was summarized as it pertains to the design and placement of berms. Initial findings from an ongoing monitoring project at the Fort Myers Beach, FL, berm were summarized, and additional research goals were identified.

ADDITIONAL INFORMATION. This Coastal and Hydraulics Engineering Technical Note (CHETN) was prepared by Tanya M. Beck, Dr. Julie D. Rosati, and James Rosati, US Army Engineer Research and Development Center (ERDC), Coastal and Hydraulics Laboratory (CHL). This CHETN is a product of the Geomorphology work unit of the Coastal Inlets Research Program (CIRP), and the Regional Sediment Management (RSM) program. These programs are conducted by ERDC, CHL, Vicksburg, MS. Detailed information about the planning and engineering of the Fort Myers Nearshore Berm project was provided by James W. Lagrone, US Army Corps of Engineers Jacksonville District, Jacksonville, FL. Information about the CIRP can be obtained from the CIRP web site http://cirp.wes.army.mil/cirp Information about the Regional Sediment Management program can be obtained from the RSM web site http://rsm.usace.army.mil

Questions pertaining to this CHETN may be addressed to:

Tanya M. Beck

Linda S. Lillycrop

(RSM Program Manager)
Tanya.M.Beck@usace.army.mil

Linda.S.Lillycrop@usace.army.mil

This ERDC/CHL CHETN-XIV-19 should be cited as follows:

Beck, T. M., J. D. Rosati, and J. Rosati. 2012. An update on nearshore berms in the Corps of Engineers: Recent projects and future needs. Coastal and Hydraulics Engineering Technical Note ERDC/CHL CHETN-XIV-19. Vicksburg, MS: US Army Engineer Research and Development Center, Coastal and Hydraulics Laboratory. http://chl.erdc.usace.army.mil/library/publications/chetn/pdf/chetn-xiv-19.pdf

\section{REFERENCES.}

Allison, M. C. and C. B. Pollock. 1993. Nearshore berms: An evaluation of prototype designs. Proceedings, Coastal Zone '93. New Orleans, LA: American Society of Civil Engineers, pp 2,938-2,950.

Barnard, P. L., L. H. Erikson, J. E. Hansen, and E. Elias. 2009. The Performance of nearshore dredge disposal at Ocean Beach, San Francisco, California, 2005-2007. Open-File Report 2008-13. Washington DC: US Geological Survey, http://pubs.usgs.gov/of/2008/1347/

Brutsche, K. and P. Wang. 2011. First year morphological evolution of an artificial berm at Fort Myers Beach, Florida. Coastal and Hydraulics Engineering Technical Note ERDC/CHL CHETN-II-54. Vicksburg, MS: US Army Engineer Research and Development Center, Coastal and Hydraulics Laboratory. http://chl.erdc.usace.army.mil/library/publications/chetn/pdf/chetn-ii-54.pdf 
Brutsche, K. 2011. Monitoring of a nearshore berm, Fort Myers Beach, Florida. Thesis submitted to the University of South Florida, Tampa, FL.

Gailani, J. Z., T. C. Lackey, and S. J. Smith. 2007. Application of the particle tracking model to predict far-field fate of sediment suspended by nearshore dredging and placement, Brunswick GA. Proceedings, WODCON XVIII. Lake Buena Vista, FL: World Dredging Congress.

Hallermeier, R. J. 1978. Uses for a calculated limit depth to beach erosion. Proceedings, $16^{\text {th }}$ Conference on Coastal Engineering, Hamburg. Germany: American Society of Civil Engineers. pp 1,4931,512 .

Hallermeier, R. J. 1981a. Critical wave conditions for sand motion initiation. Coastal Engineering Technical Aid No. 81-10. Vicksburg, MS: US Army Engineer Waterways Experiment Station, Coastal Engineering Research Center. http://naelibrary.nae.usace.army.mil/dp266/cet81010.pdf

Hallermeier, R. J. 1981b. A profile zonation for seasonal sand beaches from wave climate. Coastal Engineering. 4(3):253-277.

Hallermeier, R. J. 1983. Sand transport limits in coastal structure designs. Proceedings, Coastal Structures '83. Arlington, VA: American Society of Civil Engineers . pp 703-716.

Hands, E. B. and M. C. Allison. 1991. Mound migration in deeper water and methods of categorizing active and stable depths. Proceedings, Coastal Sediments '91. Seattle, WA: American Society of Civil Engineers. pp 1,985-1,999.

McLellan, T. N. 1990. Nearshore mound construction using dredged material. Journal of Coastal Research. (7):99-107.

McLellan, T. N. and N. C. Kraus. 1991. Design guidance for nearshore berm construction. Proceedings, Coastal Sediments '91. Seattle, WA: American Society of Civil Engineers. pp 2,000-2,011.

Smith, S. J., J. Marsh, and T. Puckette. 2007. Analysis of fluorescent sediment tracer for evaluating nearshore placement of dredged material. Proceedings, WODCON XVIII. Lake Buena Vista, FL: World Dredging Congress.

NOTE: The contents of this technical note are not to be used for advertising, publication, or promotional purposes. Citation of trade names does not constitute an official endorsement or approval of the use of such products. 